\title{
Sources of Stem Rust Resistance in Wheat-Alien Introgression Lines
}

\begin{abstract}
Mahbubjon Rahmatov, Department of Plant Breeding, Swedish University of Agricultural Sciences, SE-23053 Alnarp, Sweden; Department of Plant Pathology, University of Minnesota, St. Paul 55108; and Tajik Agrarian University, Dushanbe, 734017, Tajikistan; Matthew N. Rouse, United States Department of Agriculture-Agricultural Research Service, Cereal Disease Laboratory, St. Paul, MN 55108; and Department of Plant Pathology, University of Minnesota; Brian J. Steffenson, Department of Plant Pathology, University of Minnesota; Staffan C. Andersson, Department of Plant Breeding, Swedish University of Agricultural Sciences; Ruth Wanyera, Kenyan Agricultural and Livestock Research Organization Food Crops Research Center, Njoro, Kenya; Zacharias A. Pretorius, Department of Plant Sciences, University of Free State, Bloemfontein 9300, South Africa; Andreas Houben, Leibniz Institute of Plant Genetics and Crop Plant Research, Gatersleben, 06466 Stadt Seeland, Germany; Nazari Kumarse, Regional Cereal Rust Research Center, Aegean Agricultural Research Institute, Menemen, Izmir, Turkey; Sridhar Bhavani, International Maize and Wheat Improvement Center, ICRAF House, Nairobi, Kenya; and Eva Johansson, Department of Plant Breeding, Swedish University of Agricultural Sciences
\end{abstract}

\begin{abstract}
Rahmatov, M., Rouse, M. N., Steffenson, B. J., Andersson, S. C., Wanyera, R., Pretorius, Z. A., Houben, A., Kumarse, N., Bhavani, S., and Johansson, E. 2016. Sources of stem rust resistance in wheat-alien introgression lines. Plant Dis. 100:1101-1109.

Stem rust is one of the most devastating diseases of wheat. Widely virulent races of the pathogen in the Ug99 lineage (e.g., TTKSK) are threatening wheat production worldwide; therefore, there is an urgent need to enhance the diversity of resistance genes in the crop. The objectives of this study were to identify new sources of resistance in wheat-alien introgression derivatives from Secale cereale, Leymus mollis, L. racemosus, and Thinopyrum junceiforme, postulate genes conferring the resistance, and verify the postulated genes by use of molecular markers. From seedling tests conducted in the greenhouse, the presence of seven known stem rust resistance genes ( $\mathrm{Sr} 7 b, \mathrm{Sr} 8 a, \mathrm{Sr} 9 d, \mathrm{Sr} 10, \mathrm{Sr} 31, \mathrm{Sr} 36$, and $\mathrm{SrSatu})$ was postulated in the wheat-alien introgression lines. More lines possessed a high level of resistance in the field compared with the number of lines that were resistant at

the seedling stage. Three 2R (2D) wheat-rye substitution lines (SLU210, SLU238, and SLU239) seemed likely to possess new genes for resistance to stem rust based on their resistance pattern to 13 different stem rust races but the genes responsible could not be identified. Wheat-rye, wheat- $L$. racemosus, and wheat-L. mollis substitutions or translocations with single and multiple interchanges of chromosomes, in particular of the B and D chromosomes of wheat, were verified by a combination of genomic in situ hybridization and molecular markers. Thus, the present study identified novel resistance genes originating from different alien introgressions into the wheat genome of the evaluated lines. Such genes may prove useful in enhancing the diversity of stem rust resistance in wheat against widely virulent pathogen races such as those in the Ug99 lineage.
\end{abstract}

Stem rust or black rust of wheat, caused by Puccinia graminis f. sp. tritici Erikss. \& Henning, is one of the most devastating diseases of wheat worldwide, causing yield losses of 80 to $100 \%$ in susceptible cultivars (Singh et al. 2011). The new, widely virulent group of pathogen races in the Ug99 lineage (as exemplified by race TTKSK, also called isolate Ug99) originating from East Africa in the late 1990s has caused great concern for wheat food security. Members of this race group are virulent to the widely deployed resistance genes $\mathrm{Sr} 24$, Sr31, and Sr36 (Jin et al. 2008, 2009; Pretorius et al. 2000). The resistance genes $S r 9 h, S r 13, S r T m p$, and $S r 1 R S^{\text {Amigo }}$, found effective against race TTKSK, have been overcome by other pathogen races originating in Yemen and Africa such as TRTTF, TTKSF+, and TKTTF (Olivera et al. 2012b, 2015; Rouse et al. 2014a). Moreover, new races TTKTK and TTKTT with additional virulence to important resistance genes were recently detected (Patpour et al. 2016) and have now spread across large wheat-growing regions (Patpour et al. in press). Race TKTTF (not a member of the Ug99 lineage) recently caused severe epidemics in Ethiopia, resulting

Corresponding author: M. Rahmatov; E-mail: mahbubjon@gmail.com

Mention of trademark, proprietary product, or vendor does not constitute a guarantee or warranty of the product by the USDA, and does not imply its approval to the exclusion of other products and vendors that might also be suitable.

*The $e$-Xtra logo stands for "electronic extra" and indicates that six supplementary tables are published online.

Accepted for publication 29 January 2016.

http://dx.doi.org/10.1094/PDIS-12-15-1448-RE

(C) 2016 The American Phytopathological Society in significant economic losses (Olivera et al. 2015). Race TKTTF has spread widely and is now found in more than 10 countries, including Sweden, Denmark, and Germany (http://rusttracker.cimmyt.org/ ?page_id=6811; M. S. Hovmøller, personal communication). About 35 of the 73 described $\mathrm{Sr}$ resistance genes were derived from cultivated bread wheat but only a few are effective against races in the Ug99 lineage (Singh et al. 2015). Due to the constant evolution and mutation of $P$. graminis f. sp. tritici races, many resistance genes are rendered ineffective within a relatively short period of time.

Therefore, it is necessary to use different genetic stocks as an effective disease management strategy to broaden the genetic base of stem rust resistance in wheat when suitable resistance genes are not available in the A, B, and D genomes of wheat (Kole 2011; MujeebKazi et al. 2013). The tertiary gene pool has proven particularly useful for improving the stem rust resistance of wheat. Examples of important resistance genes include $\operatorname{Sr} 27, \operatorname{Sr} 31, \operatorname{Sr} 1 R S^{\text {Amigo }}$, and $\mathrm{Sr} 50$, originating from wheat-rye introgressions (Mago et al. 2004, 2005b; Marais and Marais 1994; The et al. 1991); Sr24, $\mathrm{Sr} 25, \mathrm{Sr} 26$, and $\mathrm{Sr} 43$, originating from wheat-Thinopyrum ponticum introgressions; $\mathrm{Sr} 44$ originating from a wheat-Thinopyrum intermedium introgression; and Sr52 originating from a wheatDasypyrum villosum introgression (Liu et al. 2010; Mago et al. 2005a; Niu et al. 2014; Qi et al. 2011). To better understand the functionality of stem rust resistance genes, Sr33 from Aegilops tauschii (Periyannan et al. 2013) and Sr35 from Triticum monococcum (Saintenac et al. 2013) were cloned and found to encode nucleotidebinding site leucine-rich repeat proteins. Although a number of stem rust resistance genes have been identified in different genetic stocks, deleterious linkage drag associations might contribute to these genes not being deployed (Singh et al. 2015).

Wild relatives are important sources of genes that can be used for bread wheat ( $T$. aestivum $\mathrm{L}$., $2 \mathrm{n}=6 \mathrm{x}=42$, AABBDD) improvement to address both abiotic and biotic stresses. Rye (Secale cereale, 
$2 \mathrm{n}=14$ ), Russian wheatgrass (Thinopyrum junceiforme, $2 \mathrm{n}=28$ ), Dune grass (Leymus mollis, $2 \mathrm{n}=28$ ), and Mammoth wild rye (L. racemosus $2 \mathrm{n}=28$ ) are members of the tertiary genepool of wheat and contain useful genes for crop improvement (Merker 1984; Merker and Lantai 1997). The introgression of genes from S. cereale, T. junceiforme, L. mollis, and L. racemosus that are highly effective against African stem rust races offers great promise for enhancing the resistance of wheat. A large number of wheat-alien introgression lines were developed in the 1980s and 2000s by the late Professor Arnulf Merker at the Swedish University of Agricultural Sciences (SLU). These wheat-alien introgression lines have mainly been tested for resistance to powdery mildew, leaf rust, and the Russian wheat aphid (Andersson et al. 2015; Ellneskogstaam and Merker 2002; Forsström and Merker 2001). No studies have been advanced on these introgression lines for resistance to stem rust. Therefore, the aims of this study were to (i) evaluate and identify possible new resistance sources through seedling and adult plant phenotyping of wheat lines with alien introgressions from $S$. cereale, $T$. junceiforme, L. mollis, and L. racemosus with different races of stem rust and (ii) validate and confirm postulated $\mathrm{Sr}$ genes with available molecular markers.

\section{Materials and Methods}

Plant materials. The plant materials used in this study included 185 winter and 94 spring wheat-alien introgression lines. These lines were developed by crossing and backcrossing strategies during 1980 to 2000 by the late Professor Arnulf Merker at SLU (Forsström and Merker 2001; Merker 1984; Merker and Lantai 1997). The wheatalien introgression lines used in this study are maintained at the Plant Breeding Department at SLU. These lines contain rye chromosomes $1 R, 2 R, 3 R, 4 R, 5 R$, and $6 R$ in the form of single and multiple disomic substitutions. Lines with wheat-rye translocations such as 1DL.1RS, 1BL.1RS, 2RL.2BS, 3DL.3RS, and 5AL.5RS and lines with multiple combinations of rye chromosome substitutions such as $1 \mathrm{R}+2 \mathrm{R}, 1 \mathrm{R}+$ $3 R, 1 R+6 R, 5 R+4 R+7 R$, and $1 R+6 R+4 R+7 R$ were also present. The investigated materials also included wheat lines with introgressed chromatin from L. racemosus, L. mollis, and T. junceiforme (Table 1).

Seedling resistance tests. The seedling resistance tests of the 279 wheat-alien introgression lines were conducted at several institutions. For the highly virulent African stem rust races, the phenotyping was done in a biosafety level-3 containment facility at the University of Minnesota in St. Paul. Other stem rust tests were conducted at the United States Department of Agriculture-Agricultural Research Service (USDA-ARS) Cereal Disease Laboratory, St. Paul, MN; University of the Free State, Bloemfontein, South Africa; and the Regional Cereal Rust Research Center (RCRRC), located at the Aegean Agricultural Research Institute, International Center for Agricultural Research in the Dry Areas (ICARDA) in Izmir, Turkey (Table 2). In South Africa, lines carrying the 3R chromosome and lines with potentially sources of resistance-that is, 22 wheatalien introgression lines, three wheat cultivars ('Sonett', 'Prins', and 'Drabant'), and triticale genotypes ('Coorong' with $\mathrm{Sr} 27$, 'Kiewiet' with $\mathrm{SrKw}$, and 'Satu' with SrSatu) — were tested at the seedling stage. In the United States, stored urediniospores were removed from a $-80^{\circ} \mathrm{C}$ freezer, immediately heat shocked for $10 \mathrm{~min}$, and then placed in a rehydration chamber (at approximately 80\% relative humidity) for 2 to $4 \mathrm{~h}$ (Rouse et al. 2011). The spores were then suspended in a lightweight mineral oil (Soltrol 170; Chevron Phillips Chemical Company LP) and inoculated onto 8- to 10-day-old seedlings at the first leaf stage. Inoculated plants were kept in a dark moist chamber at 18 to $20^{\circ} \mathrm{C}$ with relative humidity near $100 \%$ for $16 \mathrm{~h}$ to induce infection by urediniospores. Then, plants were incubated in a greenhouse at 18 to $20^{\circ} \mathrm{C}$ with supplemental light provided by pressure sodium vapor lamps ( $400 \mathrm{~W}$ and photo flux) for $16 \mathrm{~h}$ per day. The rust phenotyping protocol used at the University of the Free State is similar to the one employed in the United States (Pretorius et al. 2012). At the RCRRC, a similar methodology was followed for phenotyping experiments with race TKTTF, except that fresh urediniospores collected from plants in the field were used and suspended in the lightweight mineral oil. Ten-day-old seedlings were inoculated according to Rouse et al. (2011). Seedling infection types were recorded 14 days after incubation using a 0 -to- 4 scale, where $0 ;=$ immune to very resistant, $1=$ resistant, $2=$ moderately resistant, $3=$ moderately susceptible, $3+=$ susceptible, and $4=$ very susceptible (Jin et al. 2007; Stakman et al. 1962).

Assessment of field response to stem rust. In total, 182 winter and 65 spring wheat-alien introgression lines were evaluated for their stem rust response in the field at the Kenyan Agricultural and Livestock Research Organization (KALRO) in Njoro in 2011 and the RCRRC in 2014. Additionally, 74 spring wheat-alien introgression lines were evaluated in the field at the University of Minnesota in St. Paul in 2014. The limitation of lines tested in St. Paul was due to limited seed stocks of the winter lines, making it not possible to evaluate the entire collection in the field at St. Paul. Seed stocks of the wheat-L. racemosus and wheat-T. junceiforme lines, in particular, were extremely limited. Winter wheat-alien introgression lines were vernalized for 6 weeks at $+4^{\circ} \mathrm{C}$ before transplanting in the field in KALRO. To provide sufficient rust infection in the nurseries, mixtures of susceptible wheat cultivars were used as spreader rows surrounding and between the plots at all locations. In Njoro, the spreader rows were inoculated at the booting and heading stages with races TTKSK+TTKST by the needle-injection method (i.e., injecting urediniospores directly into the stems of spreader plants) and also

Table 1. Wheat-alien introgression lines and respective parents evaluated in this study

\begin{tabular}{llcl}
\hline Cross, pedigree & Plant habit & Number of lines & Type \\
\hline Triticale $^{\mathrm{a}}$ & Spring and winter & 5 & $\times$ Triticosecale \\
Wheat $^{\mathrm{a}}$ & Spring and winter & 8 & Triticum aestivum and T. carthlicum \\
Sv $876012 \times \mathrm{H}$ & Winter & 37 & Wheat-rye introgressions \\
Sv $876032 \times \mathrm{H} \times \mathrm{K}$ & Winter & 54 & Wheat-rye introgressions \\
Sv $856003 \times \mathrm{H}$ & Winter & 6 & Wheat-rye introgressions \\
Sub $1 \mathrm{R}+2 \mathrm{R}$ & Winter & Winter & Wheat-rye introgressions \\
Malysh & Winter & 6 & Wheat-rye introgressions \\
Starke $\times$ Otello & Winter & 7 & Wheat-rye introgressions \\
Uno $\times$ Holme & Spring & 8 & Wheat-rye introgressions \\
Triticale VT828041 & Spring & 6 & Wheat-rye introgressions \\
Triticale Drira & Spring & 23 & Wheat-rye introgressions \\
Triticale Beagle & Spring & 12 & Wheat-rye introgressions \\
Triticale VT83 615 & Spring & 2 & Wheat-rye introgressions \\
Triticale VT83 591 & Spring & 4 & Wheat-rye introgressions \\
Triticale VT 82 8039 & Spring & 5 & Wheat-rye introgressions \\
3R BB14 (CIMMYT 1974) & Spring and winter & 4 & Wheat-rye introgressions \\
Leymus spp. & Spring & 34 & Wheat-Leymus spp. introgressions \\
Thinopyrum junceiforme & $\ldots$ & 16 & Wheat- $T$. junceiforme introgressions \\
Total & & 279 & $\ldots$ \\
\hline
\end{tabular}

a Parental cultivars and lines. 
by direct foliar inoculation of the urediniospore-oil suspension on spreader plants under mist-irrigated conditions (Njau et al. 2013). At Izmir, the spreader rows were inoculated three times with race TKTTF by dusting with a mixture of fresh urediniospores and talcum powder under mist-irrigated conditions. Spreader rows at the St. Paul nursery were inoculated with race MCCFC at the early tillering and heading stage using the needle-injection and direct urediniospore-oil foliar application methods (Olivera et al. 2012a). In all locations, the adult plant response to stem rust was assessed between growth stages 50 and 90 based on the Zadoks scale (Zadoks et al. 1974) when the susceptible control reached maximum (approximately 90\%) severity. Disease severity was assessed using the modified Cobb scale (Peterson et al. 1948) and adult plant infection responses were rated according to Roelfs et al. (1992). In addition, the presence of the pseudo black chaff (PBC) phenotype in some of the spring wheat-alien introgression lines were assessed on a 0-to-4 scale (Juliana et al. 2015) in Njoro and Izmir.

Molecular marker analysis. Genomic DNA was isolated from 10-day-old leaf tissue of the wheat-alien introgression lines according to the methods of Edwards et al. (1991), with some slight modifications. Initially, 40 mapped wheat simple sequence repeat (SSR) markers for the B and D chromosomes (Röder et al. 1998; Somers et al. 2004); 30 rye-specific SSR and expressed sequence tagged (EST)-derived SSR markers for the 1R, 2R, and 3R chromosomes (Hackauf and Wehling 2002; Khlestkina et al. 2004; Martis et al. 2013; Saal and Wricke 1999); and 12 Leymus EST-SSR markers for the wheat-L. racemosus introgressions (Kaur et al. 2008; Larson et al. 2012) were assayed. The diagnostic markers $X c s S r 2$ for $S r 2$ (Mago et al. 2011), SSR Xscm and STS Xiag95 for Sr31 (Mago et al. 2002; Saal and Wricke 1999), SSR Xstm773 for Sr36 (Tsilo et al. 2008), and VENTRIUP-LN2 for Sr38 (Helguera et al. 2003) were also assayed. The polymerase chain reaction (PCR) master mix for all markers consisted of $2 \mu \mathrm{l}$ of $25 \mathrm{ng}$ of genomic DNA template, $0.6 \mu \mathrm{l}$ of a $10 \mu \mathrm{M}$ mixture of forward and reverse primers, $0.075 \mu \mathrm{l}$ $(0.5 \mathrm{U})$ of Taq polymerase, $1.75 \mu \mathrm{l}$ of $10 \times \mathrm{Ex}$ Taq Buffer $(10 \mathrm{mM}$

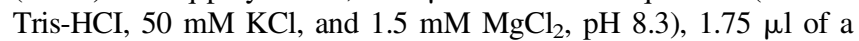
$2.5 \mathrm{mM}$ mixture of dNTP, and $9 \mu \mathrm{l}$ of double-distilled $\mathrm{H}_{2} \mathrm{O}$, bringing the total reaction volume to $15 \mu \mathrm{l}$. The $\mathrm{XcsSr} 2$ marker was digested by adding $5 \mu \mathrm{l}$ of $1.5 \mathrm{ml}$ of $10 \times$ NEB Buffer 4 and $0.5 \mu \mathrm{l}$ of $B s p \mathrm{HI}$ (10 U/ml, New England BioLabs) and incubated at $37^{\circ} \mathrm{C}$ for $1 \mathrm{~h}$ (Mago et al. 2011). PCR products were resolved on $2 \%$ agarose gels and visualized by ethidium bromide staining under UV light. The Kompetitive Allele-Specific PCR (KASP) markers for Sr2 (wMAS000005) and Sr36 (wMASO00015) (http://maswheat.ucdavis.edu/protocols/ StemRust/index.htm) were analyzed using the Applied Biosystems StepOne Plus Real-Time PCR System. Each KASP PCR consisted of $50 \mathrm{ng}$ of DNA template, $5 \mu \mathrm{l}$ of $2 \times$ KASP buffer, and $1.4 \mu \mathrm{l}$ of primer mixture. Thermal cycling conditions were $94^{\circ} \mathrm{C}$ for $15 \mathrm{~min}$, followed by 10 cycles of touchdown PCR $\left(94^{\circ} \mathrm{C}\right.$ for $20 \mathrm{~s}$ and 65 to $57^{\circ} \mathrm{C}$ for $60 \mathrm{~s}$, dropping $0.8^{\circ} \mathrm{C}$ per cycle), followed by 36 cycles of regular PCR $\left(94^{\circ} \mathrm{C}\right.$ for $20 \mathrm{~s}$ and $57^{\circ} \mathrm{C}$ for $\left.60 \mathrm{~s}\right)$, followed by fluorescence reading at $20^{\circ} \mathrm{C}$. Both thermal cycling and fluorescence reading were performed on the ABI Step One Plus Real-Time PCR system.

Genomic in situ hybridization. Genomic in situ hybridization (GISH) analysis was performed to detect alien chromatin in the resistant lines. Root tips of 2- to 3-day-old plants were treated for $24 \mathrm{~h}$ in ice-cold water and then fixed in a 3:1 mixture of ethanol and glacial acetic acid. Metaphase spreads were prepared according to the methods of Mirzaghaderi et al. (2014). Genomic DNA from S. cereale, L. mollis, and L. racemosus was used as a probe and labeled with fluorescein 12-dUTP green or Texas Red 12-dUTP by nick translation. GISH was performed as described by Schwarzacher et al. (1992). Denaturation of DNA was conducted at $80^{\circ} \mathrm{C}$ for $4 \mathrm{~min}$, followed by hybridization at $80^{\circ} \mathrm{C}$ for $2 \mathrm{~min}$, with subsequent incubation of samples in a moist chamber at $37^{\circ} \mathrm{C}$ overnight. Slides were washed in a water bath in $2 \times \mathrm{SSC}(1 \times \mathrm{SSC}$ is $0.15 \mathrm{M} \mathrm{NaCl}$ plus $0.015 \mathrm{M}$ sodium citrate $)$ for $20 \mathrm{~min}$ in darkness and, thereafter, were dehydrated in 70, 90, and $100 \%$ ethanol for $2 \mathrm{~min}$. Finally, the slides were air dried at room temperature and counterstained with 4',6-diamidino-2-phenylindole at $1 \mu \mathrm{g} / \mathrm{ml}$ in Vectashield (Vector Laboratories). Images were acquired with an epifluorescence microscope BX61 (Olympus) using a cooled CCD camera (Orca ER; Hamamatsu). Pictures were processed and merged by Adobe Photoshop (Adobe Systems Incorporated).

\section{Results}

Seedling resistance evaluation. Seedling resistance to races TTKSK, TTKST, TTTSK, TRTTF, TTTTF, TPMKC, QTHJC, RKQQC, TKTTF, and MCCFC was observed in a number of the wheat-alien introgression lines (Table 3). Individual plants were scored for their infection type and the number of resistant, susceptible, and heterogeneous (mix of susceptible and resistant) plants within lines was recorded (Table 3). Based on the virulence profile of the different races of $P$. graminis f. sp. tritici, some of the wheat-alien introgression lines were postulated to carry $\operatorname{Sr} 7 b, \operatorname{Sr} 8 a, \operatorname{Sr} 9 d$, Sr10, Sr31, Sr36, and SrSatu (Supplementary Table S1). For some of the lines, resistance genes could not be postulated because their reactions did not correspond to the avirulence or virulence profile of the races tested. The resistance genes in such lines were designated as unknown. Eleven winter wheat-rye introgression lines with the $2 \mathrm{R}$ (2B) substitution were found to be resistant (infection type $22+$ ) to races TTKSK and TTTSK although, in most cases, the lines were heterogeneous in their reaction.

The 3R chromosome is known to carry the $\mathrm{Sr} 27$ and SrSatu resistance genes, which are effective against races TTKSK, TTKST, TTTSK, TRTTF, TTTTF, RKQQC, QTHJC, TPMKC, TKTTF, and MCCFC. To further resolve the identified resistance, all of the $143 \mathrm{R}$ (3D) substitution, $1 \mathrm{R}+3 \mathrm{R}(1 \mathrm{D}+3 \mathrm{D})$ multiple substitution, and 3RS.3DL translocation lines were tested with the South African stem rust races BPGSC, BPGSC+SrKiewiet, and BPGSC+SrSatu. In addition, eight wheat-alien introgression lines and three wheat cultivars were tested for resistance to South African stem rust

Table 2. Origin and virulence phenotype of Puccinia graminis f. sp. tritici races used in this study

\begin{tabular}{|c|c|c|c|c|c|c|c|c|c|c|c|c|c|c|c|c|c|c|c|c|c|c|}
\hline \multirow[b]{2}{*}{ Race } & \multirow[b]{2}{*}{ Isolate } & \multirow[b]{2}{*}{ Origin } & \multicolumn{20}{|c|}{ Virulence profile $^{a}$} \\
\hline & & & 5 & 21 & $9 e$ & $7 b$ & 11 & 6 & $8 a$ & $9 g$ & 36 & $9 b$ & 30 & 17 & $9 a$ & $9 d$ & 10 & $T m p$ & 24 & 31 & 38 & $M c N$ \\
\hline TTKSK & 04KEN156/04 & Kenya & 5 & 21 & $9 e$ & $7 b$ & 11 & 6 & $8 a$ & $9 g$ & - & $9 b$ & 30 & 17 & $9 a$ & $9 d$ & 10 & - & - & 31 & 38 & $M c N$ \\
\hline TTKST & 06KEN19-V-3 & Kenya & 5 & 21 & $9 e$ & $7 b$ & 11 & 6 & $8 a$ & $9 g$ & - & $9 b$ & 30 & 17 & $9 a$ & $9 d$ & 10 & - & 24 & 31 & 38 & $M c N$ \\
\hline TTTSK & 07KEN24-4 & Kenya & 5 & 21 & $9 e$ & $7 b$ & 11 & 6 & $8 a$ & $9 g$ & 36 & $9 b$ & 30 & - & $9 a$ & $9 d$ & 10 & $T m p$ & - & 31 & 38 & $M c N$ \\
\hline TRTTF & 06YEM34-1 & Yemen & 5 & 21 & $9 e$ & $7 b$ & 11 & 6 & - & $9 g$ & 36 & $9 b$ & 30 & 17 & $9 a$ & $9 d$ & 10 & $T m p$ & - & - & 38 & $M c N$ \\
\hline TTTTF & 01MN84A-1-2 & United States & 5 & 21 & $9 e$ & $7 b$ & 11 & 6 & $8 a$ & $9 g$ & 36 & $9 b$ & 30 & 17 & $9 a$ & $9 d$ & 10 & $T m p$ & - & - & 38 & $M c N$ \\
\hline RKQQC & 99KS76A-1 & United States & 5 & 21 & - & $7 b$ & - & 6 & $8 a$ & $9 g$ & 36 & $9 b$ & - & - & $9 a$ & $9 d$ & - & - & - & - & - & $M c N$ \\
\hline QTHJC & 75ND717C & United States & 5 & 21 & - & - & 11 & 6 & $8 a$ & $9 g$ & - & $9 b$ & - & 17 & - & $9 d$ & 10 & - & - & - & - & $M c N$ \\
\hline TPMKC & 74MN1409 & United States & 5 & 21 & $9 e$ & $7 b$ & 11 & - & $8 a$ & $9 g$ & 36 & - & - & 17 & - & $9 d$ & 10 & $T m p$ & - & - & - & $M c N$ \\
\hline MCCFC & $59 \mathrm{KS} 19$ & United States & 5 & - & - & $7 b$ & - & - & - & $9 g$ & - & - & - & 17 & - & - & 10 & $T m p$ & - & - & - & $M c N$ \\
\hline TKTTF & $\ldots$ & Turkey & 5 & 21 & $9 e$ & $7 b$ & - & 6 & $8 a$ & $9 g$ & 36 & $9 b$ & 30 & 17 & $9 a$ & $9 d$ & 10 & - & - & - & - & $M c N$ \\
\hline BPGSC & UVPgt53 & South Africa & - & - & - & - & 11 & - & $8 a$ & $9 g$ & - & $9 b$ & - & - & $9 a$ & $9 d$ & 10 & - & - & - & - & $M c N$ \\
\hline BPGSC+SrKiewiet & UVPgt56 & South Africa & - & - & - & - & 11 & - & $8 a$ & $9 g$ & - & $9 b$ & - & - & $9 a$ & $9 d$ & 10 & - & - & - & - & $M c N$ \\
\hline BPGSC+SrSatu & UVPgt57 & South Africa & - & - & - & - & 11 & - & $8 a$ & $9 g$ & - & $9 b$ & - & - & $9 a$ & $9 d$ & 10 & - & - & - & - & $M c N$ \\
\hline
\end{tabular}

a Symbol: - indicates avirulence. 
races. Gene postulation results suggested the presence of SrSatu in four of the lines (SLU216, SLU217, SLU218, and SLU220) and SrSatu plus an additional gene in line SLU219. In summary, the seedling resistances found in the present materials with $1 \mathrm{R}$ (1D), 2R (2D), 3R (3D), 1R+6R (1D+6D), wheat-T. junceiforme, and wheat-L. mollis substitutions and 1BL.1RS and 5AL.5RS translocations showed the presence of $\operatorname{Sr} 7 b, \operatorname{Sr} 8 a, \operatorname{Sr} 9 d, \operatorname{Sr} 10$, $\mathrm{Sr} 31, \mathrm{Sr} 36$, and $\mathrm{SrSatu}$ as well as uncharacterized or potentially new $\mathrm{Sr}$ genes. All details of the seedling infection types of wheatalien introgressions are presented in Supplementary Table S1.

Field response to stem rust. In the field experiments carried out in Njoro, Izmir, and St. Paul, disease severity was sufficient to easily differentiate resistant and susceptible lines. Overall, $67(27.1 \%)$ of the lines in Njoro, $23(9.3 \%)$ of the lines in Izmir, and $6(8 \%)$ of the lines in St. Paul exhibited markedly reduced rust severities $(0$ to $30 \%$ ) compared with susceptible controls (approximately $90 \%$ ). Additionally, 22 lines (8.9\%) in Njoro, 90 lines (36.4\%) in Izmir, and 2 lines (3\%) in St. Paul displayed rust severities of 5 to $40 \%$ with MR-MS or MS-S infection types. Thus, these lines were susceptible at the seedling stage, yet they showed resistance in the field at the three diverse sites, suggesting that these lines have adult plant resistance (APR; Table 4; Fig. 1). All stages (seedling) of stem rust resistance response in $30(12.1 \%)$ of the lines in Njoro, 39 (15.8\%) of the lines in Izmir, and $28(37.8 \%)$ of the lines in St. Paul with severities 0 to $30 \%$ (R-MR response) and $10(4.1 \%)$ of the lines in both Njoro and Izmir with 5 to $40 \%$ severities (MR-MS and MS-MSS response) were observed in the field experiments (Table 4). Many of the lines-118 (44.8\%) in Njoro, 85 (34.1\%) in Izmir, and $38(51.3 \%)$ in St. Paul - displayed susceptible responses at the seedling and adult stages (Table 4). The spring and winter wheat parental cultivars at all locations exhibited susceptible disease responses from 50S to 80MS-S. The PBC pigmentation score was 1 to 2 in 17 spring lines (Supplementary Table S2). A major gene governing the PBC trait is linked to the slow-rusting resistance gene $\operatorname{Sr} 2$ (McFadden 1930) and was assayed in the field at Njoro and Izmir as well as with the $\mathrm{XcsSr} 2$ and wMAS000005 markers. However, none of these lines with the $\mathrm{PBC}$ phenotype was associated with gene $\mathrm{Sr} 2$. Also, the presence of $S r 2$ could not be confirmed by use of markers XcsSr2 or wMAS000005, which are specific for the gene. Hope and CS-Hope DS 3B (donors of $\mathrm{Sr} 2$ ) accessions were used as positive controls

Table 3. Number of wheat-alien introgression lines exhibiting resistant and susceptible reactions to Puccinia graminis f. sp. tritici races ${ }^{\mathrm{a}}$

\begin{tabular}{|c|c|c|c|c|c|c|c|c|c|c|c|}
\hline \multirow[b]{2}{*}{ Infection type } & \multicolumn{11}{|c|}{ Number of lines } \\
\hline & 1 Rep. TTKSK & 2 Rep. TTKSK & TTKST & TTTSK & TRTTF & TTTTF & TPMKC & QTHJC & RKQQC & TKTTF & MCCFC \\
\hline \multicolumn{12}{|l|}{ Resistant } \\
\hline$; 0$ & 30 & 31 & 38 & 22 & 20 & 17 & 14 & 32 & 35 & 18 & 32 \\
\hline ;1 & 6 & 5 & 7 & 4 & 4 & 4 & 1 & 5 & 8 & 17 & 7 \\
\hline $11+$ & $\ldots$ & $\ldots$ & 7 & $\ldots$ & 8 & 1 & 4 & 11 & 9 & 9 & 6 \\
\hline 2 & 6 & 7 & 1 & 13 & 4 & 3 & 2 & 4 & 2 & 8 & $\ldots$ \\
\hline $2+$ & 7 & 6 & 4 & 1 & 3 & 3 & 3 & 4 & 2 & 1 & 3 \\
\hline Subtotal & 49 & 49 & 57 & 40 & 39 & 28 & 24 & 56 & 56 & 53 & 48 \\
\hline \multicolumn{12}{|l|}{ Susceptible } \\
\hline 3 & 17 & 16 & 3 & 2 & 2 & 3 & 3 & 2 & 1 & 3 & $\ldots$ \\
\hline $3+$ & 178 & 138 & 113 & 225 & 174 & 67 & 54 & 66 & 67 & 215 & 68 \\
\hline 4 & 33 & 74 & 87 & 7 & 38 & 168 & 182 & 126 & 129 & 6 & 162 \\
\hline Subtotal & 228 & 228 & 203 & 234 & 214 & 238 & 239 & 194 & 197 & 224 & 230 \\
\hline Heterogeneous & 2 & 2 & 19 & 5 & 26 & 13 & 16 & 28 & 25 & 2 & 1 \\
\hline Total lines & 279 & 279 & 279 & 279 & 279 & 279 & 279 & 279 & 279 & 279 & 279 \\
\hline
\end{tabular}

${ }^{\text {a }}$ Infection types observed were based on a 0-to-4 scale (Stakman et al. 1962). Lines with ;0 to $2+$ types were considered resistant and lines with 3 to 4 types were considered susceptible. Heterogeneous type consisted of a mix of susceptible and resistance reactions in one line.

Table 4. Number of wheat-alien introgressions exhibiting adult plant resistance (APR) in Kenya, Turkey, and St. Paul ${ }^{\mathrm{a}}$

\begin{tabular}{|c|c|c|c|c|c|c|}
\hline \multirow[b]{2}{*}{ Severity } & \multirow[b]{2}{*}{ Response $^{c}$} & \multicolumn{3}{|c|}{ Number of lines ${ }^{b}$} & \multirow[b]{2}{*}{ Gene $^{\text {d }}$} & \multirow[b]{2}{*}{ Note } \\
\hline & & Kenya & Turkey & St. Paul & & \\
\hline \multicolumn{7}{|l|}{ R-RMR } \\
\hline \multirow[t]{2}{*}{$0-20$} & $\mathrm{R}$ & 47 & 17 & 4 & Minor & APR resistant and seedling susceptible \\
\hline & $\ldots$ & 21 & 23 & 28 & Major & Seedling and APR resistant \\
\hline \multirow[t]{2}{*}{$5-30$} & RMR & 20 & 6 & 2 & Minor & APR resistant and seedling susceptible \\
\hline & $\ldots$ & 9 & 16 & $\ldots$ & Major & Seedling and APR resistant \\
\hline Total & $\ldots$ & 97 & 62 & 34 & $\ldots$ & $\ldots$ \\
\hline \multicolumn{7}{|l|}{ MR-MS-MSS } \\
\hline \multirow[t]{2}{*}{$5-40$} & MR-MS & 16 & 22 & 2 & Minor & APR resistant and seedling susceptible \\
\hline & $\ldots$ & 10 & 5 & $\ldots$ & Major & Seedling and APR resistant \\
\hline \multirow[t]{2}{*}{$5-30$} & MS-MSS & 6 & 68 & $\ldots$ & Minor & APR resistant and seedling susceptible \\
\hline & $\ldots$ & $\ldots$ & 5 & $\ldots$ & Major & Seedling and APR resistant \\
\hline Total & $\ldots$ & 32 & 100 & 2 & $\ldots$ & $\ldots$ \\
\hline \multicolumn{7}{|l|}{ MSS-S } \\
\hline $40-70$ and $50-100$ & MS-S and S & 118 & 85 & 38 & None & APR and seedling susceptible \\
\hline Total & $\ldots$ & 118 & 85 & 38 & $\ldots$ & $\ldots$ \\
\hline \multicolumn{7}{|c|}{$\begin{array}{l}\text { APR was evaluated based on the Cobb Scale (Peterson et al. 1948) and host response to infection based on pustule type and size (Roelfs et al. 1992). Lines } \\
\text { exhibiting severity scores ranging from } 0 \text { to } 30 \text { RMR may carry four or five APR genes (Singh et al. 2014). The lines exhibiting } 5 \text { to } 40 \text { MR-MS or } 5 \text { to } 30 \\
\text { MS-MSS may carry two or three minor genes that implicate for slow rusting or partial resistance. Lines with } 40 \text { to } 70 \text { MSS and } 50 \text { to } 100 \mathrm{~S} \text { did not possess } \\
\text { APR in the field. However, presence of APR genes in combination with for or five minor genes usually display high level of resistance (Singh et al. 2014). } \\
\text { b In St. Paul, only the spring materials were tested for APR. }\end{array}$} \\
\hline
\end{tabular}


for the XcsSr2 and wMASO00005 markers. The expected fragment size of 172 bp was found in the $S r 2$ donors (Hope and CS-Hope DS 3B) for the $X c s S r 2$ marker whereas, for the wheat-alien introgression lines, the fragment size was about $240 \mathrm{bp}$. Using the wMAS000005 marker, Hope and CS-Hope DS 3B gave a signal in the VIC (fluorescent dye) assay, while the wheat-alien introgression lines gave a signal in the FAM (fluorescent dye) assay.

Molecular marker validation. To validate the presence of the postulated resistance genes, a number of markers were used. Five lines with $1 \mathrm{R}$ (1D) and two lines with 2R (2D) wheat-rye substitutions were postulated to carry $\mathrm{Sr} 36$. In addition, three lines with wheat- $L$. racemosus substitutions and translocation were postulated to carry Sr36 and validated with the KASP $w M A S 0000015$ and SSR Xstm773 (155 bp) markers. By applying the wMAS0000015 marker, lines with $\mathrm{Sr} 36$ were detected by the VIC signal, and those without the gene were detected by the FAM signal. Two lines were evaluated with the Xscm 9 (220 bp) and Iag95 (1,100 bp) markers for the presence of the $\operatorname{Sr} 31$ gene located on the 1BL.1RS wheatrye translocation. The resistance spectra of some lines were phenotypically similar to other lines known to carry the $\mathrm{Sr} 38$ gene. In these lines, the VENTRIUP-LN2 marker was used for verification but the resistance gene was not detected. Details of the molecular marker validation in wheat-alien introgression lines are shown in Supplementary Table S2.

GISH analysis. The chromosome constitution of selected wheatalien introgression lines was characterized by GISH at mitotic metaphase. In most of the lines, 42 chromosomes were present but, in some lines, signals for the presence of one, two, and five alien chromosome pairs were indicated. In general, one or two pairs of chromosomes from $S$. cereal or L. racemosus or five pairs of chromosomes from L. mollis were revealed (Fig. 2). In addition to GISH, a number of selected polymorphic wheat (30 markers), rye (14 markers), and Leymus SSR (5 markers) markers were used (Table 5; Supplementary Tables S3, S4, S5, and S6). Specific molecular markers for L. mollis and T. junceiforme were not applied, due to a lack of availability of such markers. In most cases, the D genome chromosomes of wheat were replaced. Thus, in most wheat-rye translocations and substitutions, the rye chromosomes $1 \mathrm{R}, 2 \mathrm{R}$, and $3 \mathrm{R}$ replaced the $1 \mathrm{~B}$ and $1 \mathrm{D}, 2 \mathrm{~B}$ and $2 \mathrm{D}$, and $3 \mathrm{D}$ wheat chromosomes, respectively. For the L. racemosus introgressions, two lines were identified as having substitutions and one line as possessing a translocation in the 6D wheat chromosome. All details of GISH and molecular marker analyses are presented in Supplementary Tables S3, S4, S5, and S6.

\section{Discussion}

The seedling and adult stage screening of wheat-alien introgression lines followed by GISH and molecular marker analyses clearly showed the presence of new stem rust resistance genes in the material studied. In summary, three of the 2R (2D) (SLU210, SLU238, and SLU239) substitution lines were resistant to all evaluated stem rust races at both the seedling and adult plant stages. Moreover, seven of the T. junceiforme (SLU251, SLU252, SLU253, SLU255, SLU256, SLU274, and SLU275) and one of the 3R (3D) (SLU214) wheat-alien introgressions were also identified as potential sources of new stem rust resistance genes because these lines were highly resistant to race TTKSK and TTTSK. Previous studies have documented several stem rust resistance genes (i.e., Sr27, SrSatu, Sr31, $S r 50$, and $\operatorname{Sr} 1 R S^{\text {Amigo }}$ ) derived from S. cereale (Mago et al. 2004, 2005b; Marais and Marais 1994; The et al. 1991). Moreover, of the approximately $70 \mathrm{Sr}$ genes recently cataloged to be effective against $P$. graminis f. sp. tritici races, including those in the Ug99 lineage, most are derived from alien species (Mujeeb-Kazi et al. 2013; Pumphrey et al. 2012; Singh et al. 2015). A number of the stem rust resistance genes derived from wheat-alien species have been transferred to wheat through wide hybridization (Dundas et al. 2007; Gill et al. 2006; Mujeeb-Kazi et al. 2013; Xu et al. 2009). In recent efforts to identify additional genes for resistance to TTKSK and other stem rust races, a large and diverse collection of wheatalien germplasm was evaluated at both seedling and adult stages, indicating that the alien species are extremely rich sources of genes for resistance (Evanega et al. 2014; Mujeeb-Kazi et al. 2013). Wheat-alien introgressions have also been used as a method to transfer other important traits into wheat; for example, S. cereale has served as a source of resistance to all rusts and powdery mildew (Sr31/Yr9/Lr26/Pm8) (Friebe et al. 1996), resistance to cereal aphid and Hessian fly (Crespo-Herrera et al. 2013; Hysing et al. 2007), and significant genetic diversity for yield potential, drought and salinity tolerance, micronutrient content, and further additive genetic variation for wheat improvement (Mujeeb-Kazi et al. 2013; Peake et al. 2011). Because no stem rust resistance genes have previously been described from $S$. cereale chromosome $2 \mathrm{R}$ or from $T$. junceiforme, these genetic resources possess new stem rust resistance genes.

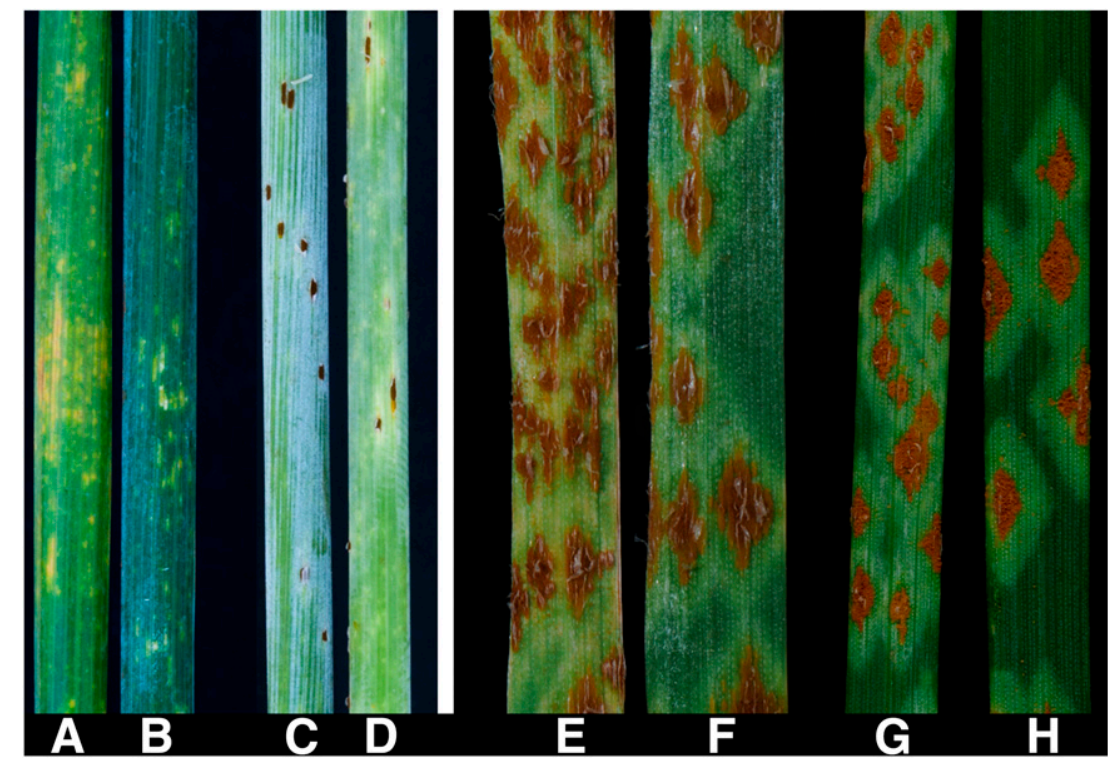

Fig. 1. Adult plant stem rust responses of A, SLU107; B, SLU157; C, SLU221; and D, SLU117 in the field in Kenya and seedling infection types of E, SLU107; F, SLU157; G, SLU221; and H, SLU117 of wheat-alien introgression lines to race TTKSK. Adult plant severity scoring was based on the modified Cobb scale (Peterson et al. 1948) and the host response to infection was assessed according to Roelfs et al. (1992). Seedling infection reactions to race TTKSK were assessed using a 0-to-4 scale (Stakman et al. 1962). 
A number of the lines evaluated in this study showed the likely presence of previously reported stem rust resistance genes. For example, the presence of $S r 31$ was inferred in two 1BL.1RS wheat-rye translocation lines (SLU168 and SLU173) based on the molecular markers Xscm9 and Xiag95 (Mago et al. 2002; Saal and Wricke 1999). $S r 31$ has been deployed widely and provided stable resistance against stem rust races for over 30 years in commercial wheat cultivars (Singh et al. 2008). Furthermore, $S r 36$ has been a key resistance gene in winter and spring wheats worldwide (Singh et al. 2011). The use of the molecular marker Xstm773 (Tsilo et al. 2008) and wMAS000015 (http://maswheat.ucdavis.edu/protocols/Sr36/index.htm) indicated the presence of $\mathrm{Sr} 36$ in 10 spring lines. However, both $\mathrm{Sr} 31$ and $\mathrm{Sr} 36$ are ineffective against the virulent race TTTSK (Jin et al. 2009; Pretorius et al. 2000). Thus, based on the susceptible reactions of seven lines (SLU251, SLU252, SLU253, SLU255, SLU256, SLU274, and SLU275) to races TTTSK, TPMKC, TTTTF, RKQCC, TRTTF, and TKTTF, it is likely that $S r 36$ is present. However, subsequent DNA fingerprinting with markers Xstm773 and wMAS000015 indicated the absence of the $S r 36$ gene. Also, based on the assays with the South African races of BPGSC, BPGSC+SrKiewiet, and BPGSC+SrSatu, four of the spring lines were highly resistant and, therefore, postulated to carry SrSatu or this gene together with an additional unknown resistance gene. SrSatu is the most commonly used stem rust resistance gene in triticale breeding and is widely distributed in CIMMYT triticale germplasm (Olivera et al. 2013; Zhang et al. 2010). Aside from the above-mentioned resistance genes, $S r 7 b$ was postulated in three spring lines, $S r 8 a$ in two winter lines, $S r 9 d$ in two winter lines, and $\mathrm{Sr} 10$ in five spring and two winter lines. These four genes originated from Triticum aestivum and T. turgidum and are ineffective against races in the Ug99 lineage (Singh et al. 2011). To conclude, the majority of the wheat-alien introgression lines with unknown genes (138 lines) exhibited a high level of resistance to some of the tested stem rust races with a broad range of virulence but a total of 110 of these lines were highly susceptible to all races at the seedling stage. It has been proposed that wheat lines often exhibit seedling susceptibility to rust diseases but possess multiple minor genes that are effective only at the adult plant stage (Singh et al. 2014). In previous studies, the effects of the $\mathrm{Sr} 2$ (Yr30/Lr27), Sr55 (Yr46/Lr67), Sr57 (Yr18/Lr34), and Sr58 (Yr29/Lr46) loci have been characterized to carry pleiotropic APR genes (Singh et al. 2015). Moreover, $\operatorname{Sr} 12$ and Sr56 were found to act in concert in conferring APR (Bansal et al. 2014; Rouse et al. 2014b). To fully elucidate the genetic architecture of APR, molecular mapping studies are a highly effective approach (Yu et al. 2014). In total, three of the 2R (2D) wheat-rye substitution lines (from triticale line VT828041 and 'Beagle') showed a high level of resistance to all $13 P$. graminis $\mathrm{f}$. sp. tritici races (including South African races) used in this investigation. We found that the $1 \mathrm{R}$ (1D), 3R (3D), and 3DL.3RS wheat-rye substitutions and translocation lines (SLU183, SLU184, SLU185, SLU186, SLU189, SLU190, SLU213, SLU214, SLU215 SLU321, SLU232, and SLU233) from VT828041 and Beagle triticale were not resistant to all tested races. Further studies are needed to clarify the genetic basis of resistance observed in several lines. Interestingly, a relatively high proportion of the lines were heterogeneous in their reaction to the races TTKST, TRTTF, TTTTF, TPMKC, QTHJC, and RKQQC, while only a few lines were heterogeneous to races TTKSK, TTTSK, TKTTF, and MCCFC (Table 3). This could be due to the fact that, in most of
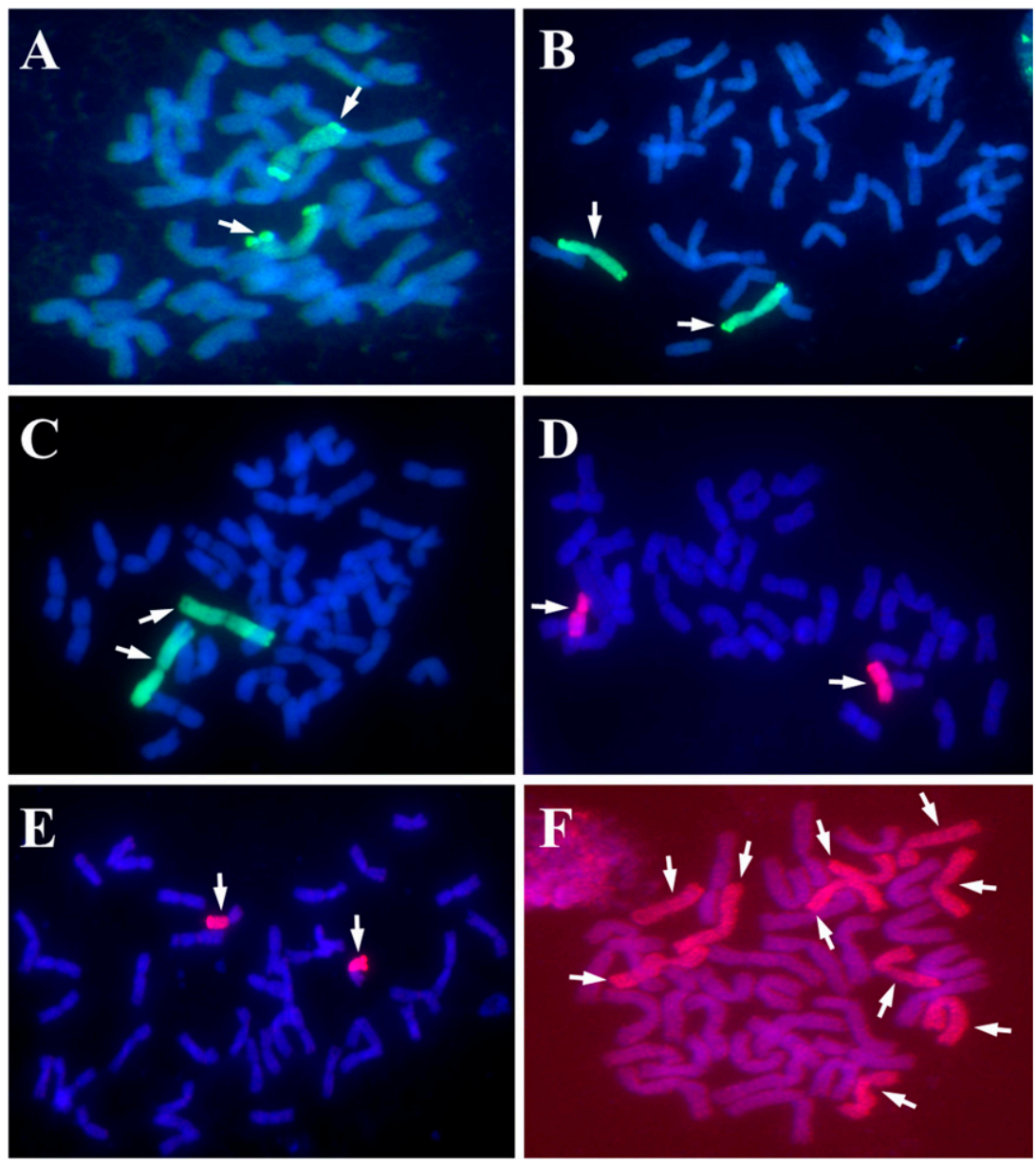

Fig. 2. Genomic in situ hybridization patterns of wheat-rye, wheat-Leymus racemosus, and wheat-L. mollis substitutions and translocation lines. A, SLU190, 1R (1D) substitution with $2 n=40+2 ;$ B, SLU238, 2R (2D) substitution with $2 n=40+2 ;$ C, SLU219, 3R (3D) substitution with $2 n=40+2 ;$ D, SLU235, wheat-L. racemosus substitution with $2 n=40+2$; $\mathrm{E}$, SLU237, wheat-L. racemosus translocation with $2 \mathrm{n}=40+2$; and $\mathrm{F}$, SLU176, wheat-L. mollis substitution with $2 \mathrm{n}=32+10$. All chromosomes were counterstained with 4',6-diamidino-2-phenylindole (in blue) and rye-specific signals are shown in green. Chromosomes of $L$. racemosus and $L$. mollis chromosomes are shown in red. Scale bar $=10 \mu \mathrm{m}$. 
the heterogeneous lines (SLU73 to SLU84), the 2R (2B) wheatrye substitution was involved. Further tests with a wider array of races or genetic analysis are needed to define what genes are responsible for the seedling resistances observed among heterogeneous lines.

For a number of lines susceptible at the seedling stage, field testing indicated the presence of varying levels of APR. The resistance identified from seedling tests to races TTKSK, TKTTF, and MCCFC remained highly effective in the field experiments (Table 4). Lines exhibiting severity scores ranging from 0 to 20,10 to 30,5 to 30 , and 5 to 40 (Table 4) might carry multiple minor-effect resistance genes. APR is known as a complex trait conferred by a number of quantitative trait loci (QTL). The combination of several of these minor-effect QTL can lead to APR or slow-rusting resistance (Singh et al. 2013b). APR is also often associated with additive and epistatic interactions (Singh et al. 2013a). Recent results on 1BL.1RS and 2RL.2BS double wheat-rye translocation lines have clearly shown that APR resistance against race TTKSK is likely due to the presence of multiple genes (Rahmatov et al. 2015). Furthermore, lines with high levels of stripe, leaf, and stem rust resistance have been reported to carry combinations of more than one APR gene, although analyses to understand the genetic background of such sources is necessary in for each case (Singh et al. 2014). Also, the genetic background for PBC has been associated with several QTL on chromosome arms 2DS, 3BS, 4AL, and 7DS (Singh et al. 2013a). Depending on the genotype and environment, $\mathrm{Sr} 2$ is sometimes strongly associated with PBC (McFadden 1930). The genetic background effects with multiple genes and variations in the linkage relationships between PBC and $\mathrm{Sr} 2$ can explain our results of markers $\mathrm{XcsSr} 2$ and $w M A S 000005$ showing no association between PBC and $S r 2$. Likewise, the black glume color similar to PBC has also been mapped to chromosome $1 \mathrm{~A}$ in a common wheat (Khlestkina et al. 2006). In general, several of the wheat-alien introgression lines in the present study, evaluated for field stem rust response at three locations, exhibited the possible presence of minor-effect resistance genes. Further studies are needed to characterize the genetic basis of resistance in these lines.

Table 5. Genomic in situ hybridization (GISH) and molecular marker results of wheat-alien introgression lines ${ }^{\mathrm{a}}$

\begin{tabular}{|c|c|c|c|c|c|c|c|}
\hline \multirow[b]{2}{*}{ Germplasm $^{\text {b }}$} & \multicolumn{3}{|c|}{ GISH and molecular analysis } & \multirow[b]{2}{*}{ Introgression $^{c}$} & \multirow[b]{2}{*}{ Chromosome number } & \multirow[b]{2}{*}{ Note } & \multirow[b]{2}{*}{$S r$ genes $^{d}$} \\
\hline & Rye & Leymus & Wheat & & & & \\
\hline SLU50 & 1R present & $\ldots$ & 1D absent & Substitution & $40+21 \mathrm{R}(1 \mathrm{D})$ & $1 \mathrm{R}$ replaced $1 \mathrm{D}$ & Unknown \\
\hline SLU56 & 1R present & $\ldots$ & 1D absent & Substitution & $40+21 \mathrm{R}(1 \mathrm{D})$ & $1 \mathrm{R}$ replaced $1 \mathrm{D}$ & Unknown \\
\hline SLU168 & 1RS present & $\ldots$ & 1BS absent & Translocation & 42 1BL.1RS & 1RS present & Sr31 \\
\hline SLU173 & 1RS present & $\ldots$ & 1BS absent & Translocation & 42 1BL.1RS & 1RS present & Sr31 \\
\hline SLU183 & $1 \mathrm{R}$ present & $\ldots$ & 1D absent & Substitution & $40+21 \mathrm{R}(1 \mathrm{D})$ & $1 \mathrm{R}$ replaced $1 \mathrm{D}$ & Unknown \\
\hline SLU188 & Rye absent & $\ldots$ & Wheat present & Normal wheat & 42 AABBDD & Normal wheat & Unknown \\
\hline SLU190 & 1R present & $\ldots$ & 1D absent & Substitution & $40+21 \mathrm{R}(1 \mathrm{D})$ & $1 \mathrm{R}$ replaced $1 \mathrm{D}$ & Sr36 \\
\hline SLU193 & $1 \mathrm{R}$ present & $\ldots$ & 1D absent & Substitution & $40+21 \mathrm{R}(1 \mathrm{D})$ & $1 \mathrm{R}$ replaced $1 \mathrm{D}$ & Sr36 \\
\hline SLU196 & 1R present & $\ldots$ & 1D absent & Substitution & $40+21 \mathrm{R}(1 \mathrm{D})$ & $1 \mathrm{R}$ replaced $1 \mathrm{D}$ & Unknown \\
\hline SLU198 & $1 \mathrm{R}$ present & $\ldots$ & 1D absent & Substitution & $40+2$ 1R (1D) & $1 \mathrm{R}$ replaced $1 \mathrm{D}$ & Unknown \\
\hline SLU199 & $1 \mathrm{R}$ present & $\ldots$ & 1D absent & Substitution & $40+21 \mathrm{R}(1 \mathrm{D})$ & $1 \mathrm{R}$ replaced $1 \mathrm{D}$ & Unknown \\
\hline SLU208 & $1 \mathrm{R}$ present & $\ldots$ & 1DS absent & Translocation & 42, 1RS.1DL & $1 \mathrm{RS}$ replaced $1 \mathrm{DS}$ & Unknown \\
\hline SLU234 & $1 \mathrm{R}$ present & $\ldots$ & 1DS absent & Translocation & $42,1 \mathrm{RS} .1 \mathrm{DL}$ & 1RS replaced 1DS & $S r 7 b$ \\
\hline SLU73 to SLU83 & $2 \mathrm{R}$ present & $\ldots$ & 2B absent & Substitution & $40+2,2 \mathrm{R}(2 \mathrm{~B})$ & $2 \mathrm{R}$ replaced $2 \mathrm{~B}$ & Unknown \\
\hline SLU209 & $2 \mathrm{R}$ present & $\ldots$ & 2D absent & Substitution & $40+2,2 \mathrm{R}(2 \mathrm{D})$ & $2 \mathrm{R}$ replaced $2 \mathrm{D}$ & $36,+$ \\
\hline SLU210 & $2 \mathrm{R}$ present & $\ldots$ & $2 \mathrm{D}$ absent & Substitution & $40+2,2 \mathrm{R}(2 \mathrm{D})$ & $2 \mathrm{R}$ replaced $2 \mathrm{D}$ & $36,+$ \\
\hline SLU212 & $2 \mathrm{R}$ present & $\ldots$ & 2D absent & Substitution & $40+2,2 \mathrm{R}(2 \mathrm{D})$ & $2 \mathrm{R}$ replaced $2 \mathrm{D}$ & Unknown \\
\hline SLU223 & $2 \mathrm{R}$ present & $\ldots$ & $2 \mathrm{D}$ absent & Substitution & $40+2,2 \mathrm{R}(2 \mathrm{D})$ & $2 \mathrm{R}$ replaced $2 \mathrm{D}$ & Unknown \\
\hline SLU238 & $2 \mathrm{R}$ present & $\ldots$ & 2D absent & Substitution & $40+2,2 \mathrm{R}(2 \mathrm{D})$ & $2 \mathrm{R}$ replaced $2 \mathrm{D}$ & Unknown \\
\hline SLU239 & $2 \mathrm{R}$ present & $\ldots$ & $2 \mathrm{D}$ absent & Substitution & $40+2,2 \mathrm{R}(2 \mathrm{D})$ & $2 \mathrm{R}$ replaced $2 \mathrm{D}$ & Unknown \\
\hline SLU213 & $3 \mathrm{R}$ present & $\ldots$ & 3D absent & Substitution & $40+2,3 R(3 D)$ & $3 \mathrm{R}$ replaced $3 \mathrm{D}$ & Unknown \\
\hline SLU214 & $3 \mathrm{R}$ present & $\ldots$ & 3D absent & Substitution & $40+2,3 \mathrm{R}(3 \mathrm{D})$ & $3 \mathrm{R}$ replaced $3 \mathrm{D}$ & Unknown \\
\hline SLU215 & 3R present & $\ldots$ & 3D absent & Substitution & $40+2,3 \mathrm{R}(3 \mathrm{D})$ & $3 \mathrm{R}$ replaced $3 \mathrm{D}$ & Unknown \\
\hline SLU216 & 3R present & $\ldots$ & 3D absent & Substitution & $40+2,3 R(3 D)$ & $3 \mathrm{R}$ replaced $3 \mathrm{D}$ & SrSatu \\
\hline SLU217 & 3R present & $\ldots$ & 3D absent & Substitution & $40+2,3 \mathrm{R}(3 \mathrm{D})$ & $3 \mathrm{R}$ replaced $3 \mathrm{D}$ & SrSatu \\
\hline SLU218 & 3R present & $\ldots$ & 3D absent & Substitution & $40+2,3 \mathrm{R}(3 \mathrm{D})$ & $3 \mathrm{R}$ replaced $3 \mathrm{D}$ & SrSatu \\
\hline SLU219 & 3R present & $\ldots$ & 3D absent & Substitution & $40+2,3 R(3 D)$ & $3 \mathrm{R}$ replaced $3 \mathrm{D}$ & SrSatu,+ \\
\hline SLU220 & $3 \mathrm{R}$ present & $\ldots$ & 3D absent & Substitution & $40+2,3 \mathrm{R}(3 \mathrm{D})$ & $3 \mathrm{R}$ replaced $3 \mathrm{D}$ & SrSatu \\
\hline SLU221 & 3R present & $\ldots$ & 3D absent & Substitution & $40+2,3 \mathrm{R}(3 \mathrm{D})$ & $3 \mathrm{R}$ replaced 3D & Unknown \\
\hline SLU231 & 3R present & $\ldots$ & 3DS absent & Translocation & 3RS.3DL & 3RS replaced 3DS & $S r 7 b$ \\
\hline SLU232 & 3R present & $\ldots$ & 3DS absent & Translocation & 3RS.3DL & 3RS replaced 3DS & $S r 7 b$ \\
\hline SLU233 & $3 \mathrm{R}$ present & $\ldots$ & 3DS absent & Translocation & 3RS.3DL & 3RS replaced 3DS & Unknown \\
\hline SLU229 & $1 \mathrm{R}+6 \mathrm{R}$ present & $\ldots$ & $1 \mathrm{D}+6 \mathrm{D}$ absent & Substitution & $38+4,1 \mathrm{R}+6 \mathrm{R}(1 \mathrm{D}+6 \mathrm{R})$ & $1 R+6 R$ replaced $1 D+6 D$ & Unknown \\
\hline SLU230 & $1 \mathrm{R}+3 \mathrm{R}$ present & $\ldots$ & $1 \mathrm{D}+3 \mathrm{D}$ absent & Substitution & $38+4,1 R+3 R(1 D+3 R)$ & $1 R+3 R$ replaced $1 D+3 D$ & Unknown \\
\hline SLU176 & Leymus mollis & NsNsXmXm & $\ldots$ & Substitution & $32+10$ & 5 pairs of $L$. mollis & Unknown \\
\hline SLU177 & L. mollis & NsNsXmXm & $\ldots$ & Substitution & $30+10$ & 5 pairs of L. mollis & Unknown \\
\hline SLU178 & L. mollis & NsNsXmXm & $\ldots$ & Substitution & $30+10$ & 5 pairs of L. mollis & Unknown \\
\hline SLU235 & L. racemousus & $\mathrm{NsXm}$ & $6 \mathrm{D}$ absent & Substitution & $40+2(6 \mathrm{D})$ & 2 pairs of L. racemousus & Sr36 \\
\hline SLU236 & L. racemousus & NsXm & $6 \mathrm{D}$ absent & Substitution & $40+2(6 \mathrm{D})$ & 2 pairs of $L$. racemousus & Sr36 \\
\hline SLU237 & L. racemousus & $\mathrm{NsXm}$ & $6 \mathrm{D}$ absent & Translocation & 42 (6DL) & 2 pairs of $L$. racemousus & Sr36 \\
\hline
\end{tabular}


By using GISH in combination with molecular markers, we showed that lines with the $2 \mathrm{R}(2 \mathrm{D})$ and $3 \mathrm{R}(3 \mathrm{D})$ wheat-rye substitutions were resistant to all tested races, and the resistances were likely from rye. In the present study, the combination of GISH together with molecular markers for wheat, rye, and $L$. racemosus unequivocally validated the presence of alien chromatin introgressed into wheat (Table 5; Fig. 2). Both cytogenetic and molecular analyses supported the contention that most lines had the following chromosome composition: $2 \mathrm{n}=40+21 \mathrm{R}(1 \mathrm{D}), 2 \mathrm{n}=40+22 \mathrm{R}(2 \mathrm{~B}), 2 \mathrm{n}=40+22 \mathrm{R}(2 \mathrm{D})$, $2 n=40+23 R$ (3D), $2 n=42$ 1DL.1RS, and $2 n=42$ 3DL.3RS. Therefore, our study agrees with previous studies (Merker 1975, 1979, 1984) showing that introgressions of alien chromosomes were primarily in the B and D chromosomes of wheat. Wheat-alien addition, substitution, and translocation lines have been successfully used in wheat improvement. However, for stem rust resistance, translocation lines are preferred due to the smaller introgression of alien chromatin, less linkage drag, and regular meiotic behavior (Friebe et al. 1996; Liu et al. 2011; Niu et al. 2011, 2014; Tiwari et al. 2014). Transfer of stem rust resistance genes such as $\mathrm{Sr} 24$ and $\mathrm{Sr} 26$ (Mago et al. 2005a), Sr39 (Niu et al. 2011), Sr43 (Niu et al. 2014), and Sr53 (Liu et al. 2011) has been successfully deployed by chromosome engineering such as radiation and $p h l b$-induced approaches. In conclusion, this study demonstrated that the wheat-alien introgression lines evaluated, particularly those from $S$. cereale and Thinopyrum junceiforme (effective only to Ug99 linage), had effective resistance against all stem rust races tested, and further genetic studies are needed to characterize these resistance sources.

\section{Acknowledgments}

We thank Monsanto's Beachell-Borlaug International Scholars Program for financial support of M. Rahmatov; Swedish University of Agricultural Sciences and K. Nazari at ICARDA, Izmir, Turkey; USDA-ARS Appropriated Project 5062-21220-021-00, USDA-ARS National Plant Disease Recovery System, and the Durable Rust Resistance in Wheat project for support of M. Rouse; the Lieberman-Okinow Endowment at the University of Minnesota, the Bill \& Melinda Gates Foundation, and the U.K. Department for International Development to Cornell University for the Borlaug Global Rust Initiative Durable Rust Resistance in Wheat Project for support of B. Steffenson; A. Case for conducting the APR assessments in St. Paul; and K. Kumke for technical assistance during GISH analysis.

\section{Literature Cited}

Andersson, S. C., Johansson, E., Baum, M., Rihawi, F., and Bouhssini, E. M. 2015. New resistance sources to Russian wheat aphid (Diuraphis noxia) in Swedish wheat substitution and translocation lines with rye (Secale cereale) and Leymus mollis. Czech J. Genet. Plant Breed. 51:162-165.

Bansal, U., Bariana, H., Wong, D., Randhawa, M., Wicker, T., Hayden, M., and Keller, B. 2014. Molecular mapping of an adult plant stem rust resistance gene $\operatorname{Sr} 56$ in winter wheat cultivar Arina. Theor. Appl. Genet. 127:1441-1448.

Crespo-Herrera, L., Smith, C. M., Singh, R., and Åhman, I. 2013. Resistance to multiple cereal aphids in wheat-alien substitution and translocation lines. Arthropod-Plant Interact. 7:535-545.

Dundas, I. S., Anugrahwati, D. R., Verlin, D. C., Park, R. F., Bariana, H. S., Mago, R., and Islam, A. K. M. R. 2007. New sources of rust resistance from alien species: Meliorating linked defects and discovery. Aust. J. Agric. Res. 58:545-549.

Edwards, K., Johnstone, C., and Thompson, C. 1991. A simple and rapid method for the preparation of plant genomic DNA for PCR analysis. Nucleic Acids Res. 19:1349.

Ellneskog-staam, P., and Merker, A. 2002. Screening for resistance to powdery mildew and brown rust in wheat-Leymus racemosus and wheat-Thinopyrum junceiforme Alloploids. Acta Agric. Scand. Sect. B Soil Plant Sci. 52:158-161.

Evanega, S. D., Singh, R. P., Coffman, R., and Pumphrey, M. O. 2014. The Borlaug Global Rust Initiative: Reducing the genetic vulnerability of wheat to rust. Pages 317-331 in: Genomics of Plant Genetic Resources. R. Tuberosa, A. Graner, and E. Frison, eds. Springer, Dordrecht, The Netherlands.

Forsström, P.-O., and Merker, A. 2001. Sources of wheat powdery mildew resistance from wheat-rye and wheat-Leymus hybrids. Hereditas 134:115-119.

Friebe, B., Jiang, J., Raupp, W. J., McIntosh, R. A., and Gill, B. S. 1996. Characterization of wheat-alien translocations conferring resistance to diseases and pests: Current status. Euphytica 91:59-87.

Gill, B. S., Friebe, B., Raupp, W. J., Wilson, D. L., Cox, T. S., Sears, R. G., BrowGuedira, G. L., and Fritz, A. K. 2006. Wheat genetics resource center: The first 25 years. Adv. Agron. 89:73-136.

Hackauf, B., and Wehling, P. 2002. Identification of microsatellite polymorphisms in an expressed portion of the rye genome. Plant Breed. 121:17-25.

Helguera, M., Khan, I. A., Kolmer, J., Lijavetzky, D., Zhong-qi, L., and Dubcovsky, J. 2003. PCR Assays for the Lr37-Yr17-Sr38 cluster of rust resistance genes and their use to develop isogenic hard red spring wheat lines. Crop Sci. 43:1839-1847.

Hysing, S.-C., Hsam, S. L. K., Singh, R. P., Huerta-Espino, J., Boyd, L. A., Koebner, R. M. D., Cambron, K. S., Johnson, J. W., Bland, D. E., Liljeroth, E., and Merker, A. 2007. Agronomic performance and multiple disease resistance in T2BS.2RL wheat-rye translocation lines. Crop Sci. 47:254-260.

Jin, Y., Singh, R. P., Ward, R. W., Wanyera, R., Kinyua, M., Njau, P., Fetch, T., Pretorius, Z. A., and Yahyaoui, A. 2007. Characterization of seedling infection types and adult plant infection responses of monogenic $S r$ gene lines to race TTKS of Puccinia graminis f. sp. tritici. Plant Dis. 91:1096-1099.

Jin, Y., Szabo, L. J., Pretorius, Z. A., Singh, R. P., Ward, R., and Fetch, T. 2008. Detection of virulence to resistance gene $\mathrm{Sr} 24$ within race TTKS of Puccinia graminis f. sp. tritici. Plant Dis. 92:923-926.

Jin, Y., Szabo, L. J., Rouse, M. N., Fetch, T., Pretorius, Z. A., Wanyera, R., and Njau, P. 2009. Detection of virulence to resistance gene Sr36 within the TTKS race lineage of Puccinia graminis f. sp. tritici. Plant Dis. 93:367-370.

Juliana, P., Rutkoski, J. E., Poland, J. A., Singh, R. P., Murugasamy, S., Natesan, S., Barbier, H., and Sorrells, M. E. 2015. Genome-wide association mapping for leaf tip necrosis and pseudo-black chaff in relation to durable rust resistance in wheat Online publication. Plant Genome 8:1-12. doi:10.3835/plantgenome2015.01.0002

Kaur, P., Larson, S., Shaun Bushman, B., Wang, R. C., Mott, I., Hole, D. Thimmapuram, J., Gong, G., and Liu, L. 2008. Genes controlling plant growth habit in Leymus (Triticeae): Maize barren stalk1 (bal), rice lax panicle, and wheat tiller inhibition (tin3) genes as possible candidates. Funct. Integr. Genomics 8:375-386.

Khlestkina, E. K., Pshenichnikova, T. A., Röder, M. S., Salina, E. A., Arbuzova, V.S., and Börner, A. 2006. Comparative mapping of genes for glume colouration and pubescence in hexaploid wheat (Triticum aestivum L.). Theor. Appl. Genet. 113:801-807.

Khlestkina, E. K., Than, M. H. M., Pestsova, E. G., Röder, M. S., Malyshev, S. V., Korzun, V., and Börner, A. 2004. Mapping of 99 new microsatellite-derived loci in rye (Secale cereale L.) including 39 expressed sequence tags. Theor. Appl. Genet. 109:725-732.

Kole, C. 2011. Wild Crop Relatives: Genomic and Breeding Resources. Cereals. Springer-Verlag, Berlin, Heidelberg, New York.

Larson, S., Kishii, M., Tsujimoto, H., Qi, L., Chen, P., Lazo, G., Jensen, K., and Wang, R. C. 2012. Leymus EST linkage maps identify 4NsL-5NsL reciprocal translocation, wheat-Leymus chromosome introgressions, and functionally important gene loci. Theor. Appl. Genet. 124:189-206.

Liu, S., Yu, L.-X., Singh, R., Jin, Y., Sorrells, M., and Anderson, J. 2010. Diagnostic and co-dominant PCR markers for wheat stem rust resistance genes Sr25 and Sr26. Theor. Appl. Genet. 120:691-697.

Liu, W., Rouse, M., Friebe, B., Jin, Y., Gill, B., and Pumphrey, M. 2011 Discovery and molecular mapping of a new gene conferring resistance to stem rust, Sr53, derived from Aegilops geniculata and characterization of spontaneous translocation stocks with reduced alien chromatin. Chromosome Res. 19:669-682.

Mago, R., Bariana, H. S., Dundas, I. S., Spielmeyer, W., Lawrence, G. J., Pryor, A. J., and Ellis, J. G. 2005a. Development of PCR markers for the selection of wheat stem rust resistance genes $S r 24$ and $S r 26$ in diverse wheat germplasm. Theor. Appl. Genet. 111:496-504.

Mago, R., Brown-Guedira, G., Dreisigacker, S., Breen, J., Jin, Y., Singh, R., Appels, R., Lagudah, E. S., Ellis, J., and Spielmeyer, W. 2011. An accurate DNA marker assay for stem rust resistance gene $\mathrm{Sr} 2$ in wheat. Theor. Appl. Genet. 122:735-744.

Mago, R., Miah, H., Lawrence, G. J., Wellings, C. R., Spielmeyer, W., Bariana, H. S., McIntosh, R. A., Pryor, A. J., and Ellis, J. G. 2005b. High-resolution mapping and mutation analysis separate the rust resistance genes $\operatorname{Sr} 31$, Lr26 and $\operatorname{Yr} 9$ on the short arm of rye chromosome 1. Theor. Appl. Genet. 112:41-50.

Mago, R., Spielmeyer, W., Lawrence, G., Lagudah, E., Ellis, J., and Pryor, A. 2002. Identification and mapping of molecular markers linked to rust resistance genes located on chromosome 1RS of rye using wheat-rye translocation lines. Theor. Appl. Genet. 104:1317-1324.

Mago, R., Spielmeyer, W., Lawrence, G. J., Ellis, J. G., and Pryor, A. J. 2004 Resistance genes for rye stem rust $(\mathrm{SrR})$ and barley powdery mildew (Mla) are located in syntenic regions on short arm of chromosome. Genome 47: 112-121.

Marais, G. F., and Marais, A. S. 1994. The derivation of compensating translocations involving homoeologous group 3 chromosomes of wheat and rye. Euphytica 79:75-80.

Martis, M. M., Zhou, R., Haseneyer, G., Schmutzer, T., Vrána, J., Kubaláková, M. König, S., Kugler, K. G., Scholz, U., Hackauf, B., Korzun, V., Schön, C.-C., Doležel, J., Bauer, E., Mayer, K. F. X., and Stein, N. 2013. Reticulate evolution of the rye genome. Plant Cell 25:3685-3698.

McFadden, E. S. 1930. A successful transfer of emmer characters to vulgare wheat J. Am. Soc. Agron. 22:1020-1034.

Merker, A. 1975. Chromosome composition of hexaploid triticale. Hereditas 80: 41-52.

Merker, A. 1979. The breeding behaviour of some rye wheat chromosome substitutions. Hereditas 91:245-255.

Merker, A. 1984. The rye genome in wheat breeding. Hereditas 100:183-191.

Merker, A., and Lantai, K. 1997. Hybrids between wheats and perennial Leymus and Thinopyrum species. Acta Agric. Scand. Sect. B Soil Plant Sci. 47:48-51. 
Mirzaghaderi, G., Houben, A., and Badaeva, E. 2014. Molecular-cytogenetic analysis of Aegilops triuncialis and identification of its chromosomes in the background of wheat. Mol. Cytogenet. 7:91.

Mujeeb-Kazi, A., Kazi, A. G., Dundas, I., Rasheed, A., Ogbonnaya, F., Kishii, M., Bonnett, D., Wang, R. R. C., Xu, S., Chen, P., Mahmood, T., Bux, H., and Farrakh, S. 2013. Chapter Four: Genetic diversity for wheat improvement as a conduit to food security. Pages 179-257 in: Advances in Agronomy, Vol. 122. D. L. Sparks, ed. Academic Press, San Diego, CA.

Niu, Z., Klindworth, D. L., Friesen, T. L., Chao, S., Jin, Y., Cai, X., and Xu, S. S. 2011. Targeted introgression of a wheat stem rust resistance gene by DNA marker-assisted chromosome engineering. Genetics 187:1011-1021.

Niu, Z., Klindworth, D. L., Yu, G., Friesen, T. L., Chao, S., Jin, Y., Cai, X., Ohm, J. B., Rasmussen, J. B., and Xu, S. S. 2014. Development and characterization of wheat lines carrying stem rust resistance gene $\mathrm{Sr} 43$ derived from Thinopyrum ponticum. Theor. Appl. Genet. 127:969-980.

Njau, P. N., Bhavani, S., Huerta-Espino, J., Keller, B., and Singh, R. P. 2013. Identification of QTL associated with durable adult plant resistance to stem rust race Ug99 in wheat cultivar 'Pavon 76'. Euphytica 190:33-44.

Olivera, P., Newcomb, M., Szabo, L. J., Rouse, M., Johnson, J., Gale, S., Luster, D. G., Hodson, D., Cox, J. A., Burgin, L., Hort, M., Gilligan, C. A., Patpour, M., Justesen, A. F., Hovmøller, M. S., Woldeab, G., Hailu, E., Hundie, B., Tadesse, K., Pumphrey, M., Singh, R. P., and Jin, Y. 2015. Phenotypic and genotypic characterization of race TKTTF of Puccinia graminis $\mathrm{f}$. sp. tritici that caused a wheat stem rust epidemic in southern Ethiopia in 2013-14. Phytopathology 105:917-928.

Olivera, P. D., Badebo, A., Xu, S. S., Klindworth, D. L., and Jin, Y. 2012a. Resistance to race TTKSK of Puccinia graminis f. sp. tritici in emmer wheat. Crop Sci. 52:2234-2242.

Olivera, P. D., Jin, Y., Rouse, M., Badebo, A., Fetch, T., Singh, R. P., and Yahyaoui, A. 2012b. Races of Puccinia graminis f. sp. tritici with combined virulence to $\mathrm{Sr} 13$ and $\mathrm{Sr} 9 \mathrm{e}$ in a field stem rust screening nursery in Ethiopia. Plant Dis. 96:623-628.

Olivera, P. D., Pretorius, Z. A., Badebo, A., and Jin, Y. 2013. Identification of resistance to races of Puccinia graminis $\mathrm{f}$. sp. tritici with broad virulence in Triticale ( $\times$ Triticosecale). Plant Dis. 97:479-484.

Patpour, M., Hovmoller, M., Justesen, A. F., Newcomb, M., Olivera Firpo, P. D., Jin, Y., Szabo, L. J., Hodson, D., Shahin, A., Wanyera, R., Habarurema, I., and Wobibi, S. 2016. Emergence of virulence to SrTmp in the Ug99 race group of wheat stem rust, Puccinia graminis f. sp. tritici, in Africa. Plant Dis. 100:522

Patpour, M., Hovmoller, M., Shahin, A., Newcomb, M., Olivera Firpo, P. D., Jin, Y., Luster, D. G., Hodson, D., Nazari, K., and Azab, M. First report of the Ug99 race group of wheat stem rust, Puccinia graminis f. sp. tritici, in Egypt in 2014. Plant Dis. In press. doi:10.1094/PDIS-08-15-0938-PDN

Peake, A. S., Gilmour, A., and Cooper, M. 2011. The 1BL/1RS translocation decreases grain yield of spring wheat germplasm in low yield environments of north-eastern Australia. Crop Pasture Sci. 62:276-288.

Periyannan, S., Moore, J., Ayliffe, M., Bansal, U., Wang, X., Huang, L., Deal, K., Luo, M., Kong, X., Bariana, H., Mago, R., McIntosh, R., Dodds, P., Dvorak, J., and Lagudah, E. 2013. The gene Sr33, an ortholog of barley Mla genes, encodes resistance to wheat stem rust race Ug99. Science 341:786-788.

Peterson, R. F., Campbell, A. B., and Hannah, A. E. 1948. A diagrammatic scale for estimating rust severity on leaves and stems of cereals. Can. J. Res. 26c: 496-500.

Pretorius, Z. A., Jin, Y., Bender, C. M., Herselman, L., and Prins, R. 2012. Seedling resistance to stem rust race Ug99 and marker analysis for $\mathrm{Sr} 2, \mathrm{Sr} 24$ and $S r 31$ in South African wheat cultivars and lines. Euphytica 186:15-23.

Pretorius, Z. A., Singh, R. P., Wagoire, W. W., and Payne, T. S. 2000. Detection of virulence to wheat stem rust resistance gene Sr31 in Puccinia graminis. f. sp. tritici in Uganda. Plant Dis. 84:203.

Pumphrey, M., Friebe, B., Jin, Y., Lagudah, E., Millet, E., Pretorius, Z., Rouse, M., Singh, R., Sorrells, M., and Steffenson, B. 2012. Stocking the breeder's toolbox: An update on the status of resistance to stem rust in wheat. Pages 23-29 in: Proc. Borlaug Global Rust Initiative 2012 Tech. Workshop. Beijing.

Qi, L. L., Pumphrey, M. O., Friebe, B., Zhang, P., Qian, C., Bowden, R. L., Rouse, M. N., Jin, Y., and Gill, B. S. 2011. A novel Robertsonian translocation event leads to transfer of a stem rust resistance gene (Sr52) effective against race Ug99 from Dasypyrum villosum into bread wheat. Theor. Appl. Genet. 123:159-167.

Rahmatov, M., Garkava-Gustavsson, L., Wanyera, R., Steffenson, B., Rouse, M., and Johansson, E. 2015. Stem rust resistance in 1BL.1RS and 2RL.2BS double wheat-rye translocation lines. Czech J. Genet. Plant Breed. 51:148-154.

Röder, M. S., Korzun, V., Wendehake, K., Plaschke, J., Tixier, M.-H., Leroy, P., and Ganal, M. W. 1998. A microsatellite map of wheat. Genetics 149:2007-2023.
Roelfs, A. P., Singh, R. P., and Saari, E. E. 1992. Rust Diseases of Wheat: Concepts and Methods of Disease Management. CIMMYT, Mexico D.F.

Rouse, M., Nirmala, J., Jin, Y., Chao, S., Fetch, T., Jr., Pretorius, Z., and Hiebert, C. 2014a. Characterization of $S r 9 h$, a wheat stem rust resistance allele effective to Ug99. Theor. Appl. Genet. 127:1681-1688.

Rouse, M., Talbert, L., Singh, D., and Sherman, J. 2014b. Complementary epistasis involving Sr12 explains adult plant resistance to stem rust in Thatcher wheat (Triticum aestivum L.). Theor. Appl. Genet. 127:1549-1559.

Rouse, M. N., Wanyera, R., Njau, P., and Jin, Y. 2011. Sources of resistance to stem rust race Ug99 in spring wheat germplasm. Plant Dis. 95:762-766.

Saal, B., and Wricke, G. 1999. Development of simple sequence repeat markers in rye (Secale cereale L.). Genome 42:964-972.

Saintenac, C., Zhang, W., Salcedo, A., Rouse, M. N., Trick, H. N., Akhunov, E., and Dubcovsky, J. 2013. Identification of wheat gene Sr35 that confers resistance to Ug99 stem rust race group. Science 341:783-786.

Schwarzacher, T., Anamthawat-Jónsson, K., Harrison, G. E., Islam, A. K. M. R., Jia, J. Z., King, I. P., Leitch, A. R., Miller, T. E., Reader, S. M., Rogers, W. J. Shi, M., and Heslop-Harrison, J. S. 1992. Genomic in situ hybridization to identify alien chromosomes and chromosome segments in wheat. Theor. Appl. Genet. 84:778-786.

Singh, A., Knox, R. E., DePauw, R. M., Singh, A. K., Cuthbert, R. D., Campbell, H. L., Singh, D., Bhavani, S., Fetch, T., and Clarke, F. 2013a. Identification and mapping in spring wheat of genetic factors controlling stem rust resistance and the study of their epistatic interactions across multiple environments. Theor Appl. Genet. 126:1951-1964.

Singh, R. P., Herrera-Foessel, S., Huerta-Espino, J., Singh, S., Bhavani, S., Lan, C., and Basnet, B. 2014. Progress towards genetics and breeding for minor genes based resistance to Ug99 and other rusts in CIMMYT high-yielding spring wheat. J. Integr. Agric. 13:255-261.

Singh, R. P., Hodson, D. P., Huerta-Espino, J., Jin, Y., Bhavani, S., Njau, P., Herrera-Foessel, S., Singh, P. K., Singh, S., and Govindan, V. 2011. The emergence of Ug99 races of the stem rust fungus is a threat to world wheat production. Annu. Rev. Phytopathol. 49:465-481.

Singh, R. P., Hodson, D. P., Huerta-Espino, J., Jin, Y., Njau, P., Wanyera, R., Herrera-Foessel, S., and Ward, R. W. 2008. Will stem rust destroy the world's wheat crop? Adv. Agron. 98:271-309.

Singh, R. P., Hodson, D. P., Jin, Y., Lagudah, E. S., Ayliffe, M. A., Bhavani, S. Rouse, M. N., Pretorius, Z. A., Szabo, L. J., Huerta-Espino, J., Basnet, B. R. Lan, C., and Hovmøller, M. S. 2015. Emergence and spread of new races of wheat stem rust fungus: Continued threat to food security and prospects of genetic control. Phytopathology 105:872-884

Singh, S., Singh, R. P., Bhavani, S., Huerta-Espino, J., and Eugenio, L. V. E. 2013b. QTL mapping of slow-rusting, adult plant resistance to race Ug99 of stem rust fungus in PBW343/Muu RIL population. Theor. Appl. Genet. 126: $1367-1375$

Somers, D., Isaac, P., and Edwards, K. 2004. A high-density microsatellite consensus map for bread wheat (Triticum aestivum L.). Theor. Appl. Genet. 109:1105-1114

Stakman, E. C., Stewart, D. M., and Loegering, W. Q. 1962. Identification of Physiologic Races of Puccinia graminis var. tritici. United States Department of Agriculture, Agricultural Research Service, Beltsville, MD.

The, T. T., Gupta, R. B., Dyck, P. L., Appels, R., Hohmann, U., and McIntosh, R. A. 1991. Characterization of stem rust resistant derivatives of wheat cultivar Amigo. Euphytica 58:245-252.

Tiwari, V. K., Wang, S., Sehgal, S., Vrána, J., Friebe, B., Kubaláková, M. Chhuneja, P., Doležel, J., Akhunov, E., Kalia, B., Sabir, J., and Gill, B. S. 2014. SNP discovery for mapping alien introgressions in wheat. BMC Genomics 15:273.

Tsilo, T. J., Jin, Y., and Anderson, J. A. 2008. Diagnostic microsatellite markers for the detection of stem rust resistance gene $S r 36$ in diverse genetic backgrounds of wheat. Crop Sci. 48:253-261.

Xu, S. S., Jin, Y., Klindworth, D. L., Wang, R. R.-C., and Cai, X. 2009. Evaluation and characterization of seedling resistances to stem rust Ug99 races in wheat-alien species derivatives. Crop Sci. 49:2167-2175.

Yu, X. L., Barbier, H., Rouse, N. M., Singh, S., Singh, R. P., Bhavani, S., HuertaEspino, J., and Sorrells, M. E. 2014. A consensus map for Ug99 stem rust resistance loci in wheat. Theor. Appl. Genet. 127:1561-1581.

Zadoks, J. C., Chang, T. T., and Konzak, C. F. 1974. A decimal code for the growth stages of cereals. Weed Res. 14:415-421.

Zhang, J., Wellings, C. R., McIntosh, R. A., and Park, R. F. 2010. Seedling resistance to rust diseases in international triticale germplasm. Crop Pasture Sci. 61:1036-1048 